\title{
PATTERN OF GALL DISTRIBUTION ON Protium heptaphyllum LEAVES IN A RESTINGA OF ESPIRITO SANTO STATE
}

\author{
Rodolfo Antônio de Figueiredo \\ Departamento de Botânica \\ UNICAMP - Campinas, SP.
}

\section{RESUMO}

Muitos insetos produzem crescimentos anormais na superficie foliar de algumas plantas. O presente estudo investiga a distribuição diferencial de galhas em Protium heptaphyllum em uma restinga do sudoeste brasileiro. $\mathrm{O}$ número de folha por galhas foi contado em quatorze individuos e foi encontrada diferença estatistica na distribuição de galhas entre individuos e no mesmo individuo. Os resultados encontrados sugerem que a distribuição de galhas pode ser devida a uma susceptibilidade diferencial de $P$. heptaphylhım aos insetos galhadores, o que é consistente com a hipótese do mosaicismo genético em plantas.

\section{SUMMARY}

Many insects produce abnormal growths on plant leaf surfaces. This study investigates the differential distribution of gall on Protium heptaphyllum in a restinga of southeastern Brazil. The number of galls per leaf was counted on fourteen individuals and it was found statiscal differences in gall distributions among and within individuals. The results suggest that the distribution of galls may be due to differential susceptibility of $P$. heptaphyllum to galling insects, which is consistent with the plant genetic mosaic hypothesis. 


\section{INTRODUCTION}

Many insects parasite plants, causing abnormal tissue growths, called galls. Plants developed several barriers against herbivores, which, otherwise, developed abilities to surpass many morphological and chemical barriers, like secondary compounds ${ }^{1}$. Temporal and spatial variations in morphology, nutrition and chemical defenses in plants are important factors to phytophagous population control 1

Plant susceptibility to galls can be altered by stress conditions ${ }^{2}$ or by somatic mutations in totipotent meristems ${ }^{3}$. The "plant genetic mosaic hypothesis" 4 states that individual tree may be constituted by different genotypes and each of these genotypes may determine different susceptibility to galling insects in each branch of the tree. This differential distribution of galls among plant branches.

This study hypothesizes that plants show genetic differences among branches of the same individual (ramets) and among individuals (genets). The theoretical model asserts that if the plant is a genetic mosaic the characteristic studied (i. e. galls) will show aggregate distribution into genets (tested with analysis of variance) and variation into genets (tested with deviation of randomize average). On the contrary, randomized distribution into and among genets shows the nonexistence of genetic mosaicism. This model will be tested using distribution of galls in leaves of Protium heptaphyllum ( Burseraceae) in a restinga habitat. I tested if the gall distribution in this plant population, living in a stressed habitat, can fit to the plant genetic mosaic hypothesis.

The assumptions of the model are: mutation occurs in meristematic cells: the cells will produce, after mutation, secondary compounds with an altered secondary compounds will give a better or a worst protection to the plant against gallers; ecological and historical factors are exclused from the model; and differential distribution of galls is an indicative of genetic differences

\section{MATERIALS AND METHODS}

The study carried out in the Reserva Florestal de Linhares (19 $06^{\circ}-19^{\circ} 18^{\prime} \mathrm{S}, 39^{\circ} 45^{\prime}$ $\left.40^{\circ} 19^{\prime} \mathrm{W}\right)$, Espirito Santo State, southeastern Brazil. This area (21.800 ha) is constituted mainly by Mata Atlântica rainsforest, and $4 \%$ of the total area is characterized by restinga type vegetation 5 . In Reserve the average precipitation is above $1.300 \mathrm{~mm}$ and the annual average temperature is $22.8^{\circ} \mathrm{C}$

The studied species Protium heptaphyllum (Aublet) Marchand (Burseraceae) is a shrub, with compound leaves that is found inside forests and open areas. The leaves have many secondary compounds, like resin ducts that contains triterpenoids, proantocinines and cianogenics 6 . 
The study was carried out between July and August,1992. Area of $200 \mathrm{~m} 2$ in the resting was delimited and fourteen individuals of $P$. heptaphyllum inside it were recorded. All trees studied reached heights up to $2 \mathrm{~m}$, and were far from the forest edge, with all their leaves receiving direct insolation (the air temperature could varies between $21^{\circ} \mathrm{C}$ at morning and $51^{\circ} \mathrm{C}$ at noon). All leaves were censued, being counted the number of folioles, the number of galled folioles, and the number of galls per foliole. I collected 64 folioles at random from other five individuals $(n=320)$ outside the study area, but very close to it, to measure foliole area and age (classified as new or old by their hardness and coloration)

Statistical analysis of the differences in gall distribution were made with the KruskalWallis test, and the differences witthin individuals were tested by the deviation of randomized distribution and by the correlation coeficient ${ }^{7}$.

\section{RESULTS}

The leaves were galled by Coccidae (Homoptera) and Cecidomyiidae (Diptera) (M. A. Garcia, pers. comm.). On 1.269 leaves analysed inside the study area it was found 2.686 galls The average number of galls per foliole was $2.12 \pm 4.13(\mathrm{x} \pm 1 \mathrm{sd})$. The foliole area was $3.254 \mathrm{~mm}^{2}$ $(\mathrm{n}=320)$. Two-hundred six were considered old folioles. It was not find any correlation between foliole area and number of galls $(r=0.03)$ nor between foliole age number of galls $(r=0.04)$.

Gall distribution within individuals was aggregated $\left(s^{2} / x=8.05\right)$. The leaves that more galled folioles had the greater number of galls per foliole $(r=0.75)$, suggesting the existence of differential susceptibility to galls between the leaves. There was also a significative variance in gall number between the 14 individuals $(\mathrm{H}=70.05, \alpha=0.05, \mathrm{~F}=5.65, \mathrm{P}<0.01)$.

\section{DISCUSSION}

The differential distribution of galls on the leaves of $P$. heptaphyllum may be explained by several factors, such as insect behavior, temperature variance along the year, lifferential mortality of gallers, turnover rates, and by differential susceptibility of the branchs to the zalling insects. More detailed field and laboratory experiments should be performed to clearly locument the pattern observed and proposed a driving mechanism. Nevertheless, I hypothesize that hepattern observed is regarded to differential susceptibility of plant ramets and genets. This onjecture is supported by other studies present in literature, as follows. 
Several studies explained differences in gall distributions by genetic based biochemical variations among plants $3,8,9$. Intra-tree differential susceptibility to galling insects was also observed by Gill and Halverson ${ }^{10}$, and Gill $^{4}$ proposed that these results are consistent with the plant genetic mosaic hypothesis.

The differential distribution of leaf galls found on $P$. heptaphyllum in this study is also consistent with the hypothesis of genetic mosaicism. Following this iew line, the results of this study may be explained as products of genetic differences among leaves and individuals of this species, taking a susceptibility variance among branchs maybe caused by mutations on the leaf buds meristems

The occurence of genetic mosaicism in plants merists special attention. It has consequences in studies of auto-incompatibility systems, in studies of pollination ecology, and even in studies of plant systematics ${ }^{11}$. More studies should be undertaken, maybe using autoincompatible plant species and experimental inbreeding, to support better the hypothesis of genetic mosaicism explaining the differential distribution of galls in plants.

\section{ACKNOWLEDGMENTS}

I thank F. A. M. dos Santos, J. A. Lombardi, M. Van Sluys, P. C. Barata, G. B. Williamson, A. Sciamarelli, and L. C. Bernacci for valuable discussions and reading an earlier version of the manuscript: Companhia Vale do Rio Doce for logistic support and CAPES and M. Brown Foundation for financial support.

\section{REFERENCES CITED}

1.DENNO, R. F. \& McCLURE, M. S. Variable plants and herbivores in natural and herbivores in natural and manged system. Academic Press, New York, 1983.

2.MATTSON, S. \& HAACK, R. A. The role of drought in outbreaks of plant-eating insects Bioscience, 37:110-118, 1987

3.WHITHAM, T. G. \& SLOBODCHIKOFF, C. N. Evolution by individuals, plant-herbivore interactions, and mosaics of genetic variability: the adaptative significance of somatic mutations in plants. Oecologia, 89: $287-292,1981$ 
4.GILL, D. E. Individuals plants as genetic mosaics: ecological organisms versus evolutionary individuals. In: Plant ecology (Crawley, M. J., ed.), Blackwell scientific Publications, Oxford. 1986.

5.PEIXOTO, A. L. Considerações preliminares sobre a flora e vegetação da Reserva Florestal da CVRD (Linhares - S). Cadernos de Pesquisa - Série Botânica. Universidade Federal do Piaui, p. 41-48. 1982

6.CRONQUIST, A. An integrated system of classification of flowering plants. Columbia University Press. U. K. 1981

7. BROWER, J. E. \& Zar, J. H. Field \& Laboratory methods for general ecology. Wm. C. Brown Publishers, Iowa. 1984

8. LEWIS, W. H. Chromosomal drift, a new phenomenon in plants. Science, 168: 1115-1116. 1970.

9. MAXWELL, F. G. \& JENNINGS, R. R. Breeding plants resistant to insects. John Wiley, New York. 1980

10. GILL, D. E. \& HALVERSON, T. G. Fitness variation among branches within trees, In: Evolutionary ecology (Shorrocks, B., ed.), Blackwell Scientific Publishers, Oxford. 1984.

11. FERnANDES, G. W., FlOATE, K. D. \& NILSSON, J. A. On the identification of plant. Resumos do Congesso de Ecologia do Brasil, 2: 125. Londrina, PR. 1994 
